Jurnal InFestasi

Vol. 11, No.2, Desember 2015

Hal. 171 - 185

\title{
DETERMINAN KEPATUHAN PADA KETENTUAN PENGUNGKAPAN WAJIB LAPORAN KEUANGAN PEMERINTAH DAERAH (Studi Pada Kabupaten/Kota Di Provinsi Nusa Tenggara Barat
}

\author{
Mira Feriyanti ${ }^{1}$ \\ Hermanto ${ }^{2}$ \\ Ni Ketut Suransi 2 \\ 1 Inspektorat Kab. Lombok Timur NTB, Indonesia \\ 2 Fakultas Ekonomi, Universitas Mataram, NTB, Indonesia \\ email: mirafykhair@gmail.com
}

\begin{abstract}
This research aimed to analyze the determinants of compliance toward the provisions of mandatory disclosure of financial statements of local governments (LKPD) throughout districts / cities in West Nusa Tenggara Province which consists of eight regencies and two Cities. This research is quantitative in nature. The data used is secondary data sourced from Audit Reports on LKPD by the Supreme Audit Agency (BPK), overview of the results of BPK and data of the Central Bureau of Statistics for the period of 2011 to 2013. Data were collected by using documentation technique and literature. The analytical method used is panel data regression using the software eviews 8 . The results of the research indicate that the wealth of the region, the level of dependence, the age of administrative local government, the number of legislators, total SKPD and deviation rate based $B P K$ audit results have significant influence on the level of disclosure of financial statements of local governments, while the population and the number of audit findings do not have a significant influence on the level of disclosure $L K P D$,
\end{abstract}

Key words : Level of disclosure, the characteristics of local governments, complexity administration, $B P K$ audit results

\begin{abstract}
Abstrak
Penelitian ini bertujuan untuk menganalisis determinan kepatuhan pada ketentuan pengungkapan wajib Laporan Keuangan Pemerintah Daerah (LKPD) seluruh Kabupaten/Kota di Provinsi Nusa Tenggara Barat (NTB). Provinsi NTB terdiri dari 8 (delapan) Kabupaten dan 2 (dua) Kota. Penelitian ini merupakan penelitian kuantitatif. Data yang digunakan adalah data sekunder yang bersumber dari Laporan Hasil Pemeriksaan atas LKPD oleh Badan Pemeriksa Keuangan (BPK), ikhtisar hasil pemeriksaan BPK dan data dari Badan Pusat Statistik untuk periode tahun 2011 sampai dengan tahun 2013. Pengumpulan data dilakukan dengan teknik dokumentasi dan studi pustaka. Metode analisis yang digunakan adalah regresi data panel dengan menggunakan software eviews 8. Hasil penelitian ini menunjukkan bahwa kekayaan pemerintah daerah, tingkat ketergantungan, Umur administratif Pemerintah Daerah, jumlah anggota legislatif, jumlah Satuan Kerja Perangkat Daerah (SKPD) dan tingkat penyimpangan berdasarkan hasil audit BPK memiliki pengaruh terhadap tingkat pengungkapan laporan keuangan pemerintah daerah, sedangkan jumlah penduduk dan jumlah temuan hasil audit tidak mempunyai pengaruh terhadap tingkat pengungkapan LKPD.

Kata kunci : Tingkat pengungkapan, karakteristik pemda, kompleksitas pemerintahan, hasil audit BPK
\end{abstract}


Mira Feriyanti, Hermanto, Ni Ketut S Jurnal InFestasi Vol. 11, No.2, Desember 2015

\section{PENDAHULUAN}

Pemerintah Daerah (Pemda) adalah pihak yang menjalankan roda pemerintahan, pembangunan, dan pelayanan masyarakat. Salah satu tuntutan masyarakat terhadap penyelengara pemerintahan adalah transparansi dan akuntabilitas pengelolaan keuangan agar tercipta pemerintahan yang baik dan bersih. Penyajian Laporan Keuangan Pemerintah Daerah (LKPD) merupakan upaya Pemda untuk mewujudkan transparansi dan akuntabilitas pengeloaan keuangannya. LKPD disusun berdasarkan Standar Akuntansi Pemerintahan

Dalam perspektif agency theory, rakyat sebagai prinsipal memberikan mandat kepada pemerintah sebagai agen, untuk menjalankan tugas pemerintahan dalam rangka meningkatkan kesejahteraan rakyat. Dalam konteks lain, politisi dapat juga disebut prinsipal karena menggantikan peran rakyat, dan dapat juga dipandang sebagai agen karena menjalankan tugas pengawasan yang diberikan oleh rakyat. Implikasinya, rakyat sebagai principal secara langsung perlu melakukan pengawasan kepada agen baik pemerintah maupun para politisi. Politisi sebagai prinsipal juga memerlukan informasi untuk mengevaluasi jalannya pemerintahan. Sedangkan dalam konteks signalling theory, pemerintah berusaha untuk memberikan sinyal yang baik kepada rakyat (Evans dan Patton; 1987). Salah satu upaya pemerintah sebagai agen dan pemberian sinyal yang baik tersebut adalah dengan menyajikan LKPD yang sesuai dengan Standar Akuntansi Pemerintahan yang telah ditetapkan.

Undang-undang Nomor 17 Tahun 2003 tentang Keuangan Negara pasal 31 mengamanatkan agar Gubernur/Bupati/ Walikota meyampaikan laporan pertanggungjawaban berupa laporan keuangan yang telah diaudit oleh Badan Pemeriksa Keuangan (BPK). Penyampaian LKPD tersebut selambatlambatnya 6 (enam) bulan setelah tahun anggaran berakhir. Penyajian LKPD digunakan untuk membuat keputusan sehingga perlu dilengkapi dengan pengungkapan yang memadai (disclosure) mengenai informasiinformasi yang dapat mempengaruhi pengambilan keputusan (Mardiasmo, 2002) Suatu Standar akuntansi diperlukan sebagai pedoman dan petunjuk dalam rangka penyusunan laporan keuangan. Oleh karena itu, laporan keuangan pemerintah yang dihasilkan harus mengikuti Standar Akuntansi Pemerintahan sesuai PP Nomor 71 Tahun 2010. Hal ini juga dipertegas dari pernyataan dalam Undang-Undang Nomor 17 Tahun 2003 tentang Keuangan Negara yang mengamanatkan bahwa laporan pertanggungjawaban APBN/APBD harus disusun dan disajikan sesuai dengan Standar Akuntansi Pemerintahan. Undang-Undang Nomor 1 Tahun 2004 tentang Perbendaharan Negara juga mengamanatkan penyusunan laporan pertanggungjawaban pemerintah pusat dan daerah harus sesuai dengan Standar Akuntansi Pemerintahan.

Pengungkapan dalam laporan keuangan dibedakan menjadi dua yaitu pengungkapan wajib (mandatory disclosure) dan pengungkapan sukarela (voluntary disclosure). Mandatory disclosure merupakan pengungkapan informasi yang wajib dikemukakan sesuai dengan peraturan yang telah ditetapkan. Voluntary disclosure merupakan pengungkapan yang disajikan diluar item-item yang wajib diungkapkan sebagai tambahan informasi bagi pengguna laporan keuangan (Syafitri 2012). Tingkat pengungkapan wajib LKPD terhadap SAP di Indonesia masih rendah. Lestiani (2012) menyatakan bahwa tingkat pengungkapan wajib LKPD sebesar 35,45\% dengan menggunakan data LKPD Kabupaten/Kota di Indonesia tahun anggaran 2006. Sementara Lesmana (2010) menyatakan tingkat pengungkapan wajib yang justru lebih rendah sebesar $22 \%$ dengan menggunakan data LKPD Provinsi/ Kabupaten/Kota di Indonesia tahun 2007. Penelitian Hilmi (2010) menyatakan hal serupa bahwa tingkat pengungkapan wajib atas LKPD Provinsi di Indonesia tahun 2006-2009 adalah sebesar 44,56\%. Sementara hasil lebih tinggi diungkapkan Syafitri (2012), yang 
Mira Feriyanti, Hermanto, Ni Ketut S Jurnal InFestasi Vol. 11, No.2, Desember 2015

menyatakan bahwa tingkat pengungkapan wajib LKPD Kabupaten/ Kota di Indonesia tahun 2008-2009 sebesar 52,09\%. Kondisi tersebut membuat peneliti tertarik untuk menganalisis lebih lanjut pengungkapan wajib LKPD terhadap SAP. Penelitian ini menggunakan mandatory disclosure karena membandingkan antara pengungkapan dalam LKPD dengan yang seharusnya diungkapkan dalam SAP

Pengungkapan LKPD yang masih rendah ini juga berpengaruh terhadap opini yang diberikan oleh Badan Pemeriksa Keuangan (BPK). Menurut Ikhtisar Hasil Pemeriksaan Semester I tahun 2014 yang dilakukan BPK, opini Wajar Tanpa Pengecualian (WTP) yang diperoleh Pemerintah Daerah Kabupaten/Kota di Provinsi NTB selama tahun 2011-2013 hanya sebanyak 2 LKPD dari 30 LKPD yang diperiksa selama kurun waktu tersebut. Sedangkan sisanya mendapatka opini selain WTP, yaitu mendapat opini Wajar Tanpa Pengecualian Dengan Paragraf Penjelas (WTP DPP) sebanyak 2 LKPD, opini Wajar Dengan Pengecualian (WDP) sebanyak 24 LKPD dan Tidak memberikan Pendapat (TMP) sebanyak 2 LKPD. Itu berarti hanya sekitar 6,66 \% dari keseluruhan Pemerintah Daerah Kabupaten/Kota di Provinsi NTB yang telah menyajikan laporan keuangannya secara wajar.

Mempertimbangkan hasil penelitian -penelitian sebelumnya, penelitian ini bermaksud untuk menganalisis lebih lanjut tentang determinan kepatuhan pada ketentuan pengungkapan wajib LKPD Kabupaten/Kota di Provinsi Nusa Tenggara Barat (NTB). Penelitian ini menggunakan karakteristik pemda yang diwakili oleh kekayaan daerah, tingkat ketergantungan, umur administratif pemda dan ukuran legislatif. Kompleksitas pemerintahan diwakili oleh jumlah penduduk dan jumlah SKPD. Sedangkan hasil audit BPK diwakili oleh jumlah temuan dan tingkat penyimpangan.

Penelitian ini mengacu pada penelitian Hilmi (2010) tetapi hanya menggunakan 6 dari 7 variabel independen yang dipakai dalam penelitian tersebut yaitu kekayaan daerah, tingkat ketergantungan pada pemerintah pusat, jumlah penduduk, jumlah SKPD, temuan audit dan penyimpangan hasil audit. Sedangkan 2 (dua) variable lain yaitu umur administratif pemda dan jumlah anggota legislatif menggunakan variable yang dipakai pada penelitian Syafitri (2012).

\section{Kekayaan Pemerintah Daerah}

Kekayaan Pemda menggambarkan tingkat kemakmuran daerah tersebut (Sinaga, 2011). Kekayaan Pemda diproksikan dengan pendapatan asli daerah (PAD). Sumber PAD yang utama adalah pajak dan retribusi daerah yang berasal dari masyarakat masing-masing daerah. Dengan demikian, semakin besar PAD maka semakin tinggi partisipasi masyarakat dalam membayar pajak dan retribusi daerah, sehingga Pemda akan terdorong untuk melakukan pengungkapan secara lengkap pada laporan keuangannya agar transparan dan akuntabel. Hasil penelitian yang dilakukan Lestiani (2012) menemukan bahwa kekayaan daerah berhubungan positif dan signifikan dengan tingkat pengungkapan laporan keuangan pemerintah kabupaten/kota.

Dari uraian di atas, maka hipotesis pertama penelitian ini adalah: Kekayaan Pemda berpengaruh positif terhadap tingkat pengungkapan LKPD.

\section{Tingkat Ketergantungan Pemerintah Daerah}

Dana transfer merupakan jenis pendanaan daerah yang berasal dari pemerintah pusat atau provinsi. Oleh karena itu, pemerintah pusat ataupun provinsi akan meminta pengungkapan yang lebih sebagai upaya untuk memonitor kinerja pemerintah daerah atas penggunaan dana tersebut. Hal ini berarti semakin besar tingkat ketergantungan maka akan semakin besar tingkat pengungkapan yang dilakukan pemerintah daerah.

Penelitian Robbins dan Austin (1986) menemukan bahwa tingkat ketergantungan pemerintah kota berhubungan positif dan signifikan terhadap tingkat pengungkapan laporan keuangan pemerintah kota. Adanya ketergantungan yang besar 
Mira Feriyanti, Hermanto, Ni Ketut S Jurnal InFestasi Vol. 11, No.2, Desember 2015

memungkinkan pemerintah pusat untuk melakukan pembatasan operasi pemerintah daerah (kota) dan meminta pengungkapan lebih untuk memonitor kinerja pemerintah daerah (kota) dengan pembatasan operasi tersebut. Robbins dan Austin (1986) menemukan bahwa tingkat ketergantungan pemerintah kota berhubungan positif dan signifikan terhadap tingkat pengungkapan laporan keuangan pemerintah kota.

Hipotesis kedua penelitian ini adalah sebagai berikut : Tingkat ketergantungan berpengaruh positif terhadap tingkat pengungkapan LKPD

\section{Umur Administratif Pemerintah Daerah}

Umur administrative Pemda adalah tahun dibentuknya suatu pemerintahan daerah berdasarkan Undang-Undang pembentukan daerah tersebut. Pemerintah daerah yang memiliki umur administratif yang lebih lama akan semakin berpengalaman dan memiliki kemampuan yang lebih baik dalam menyajikan laporan keuangannya secara wajar sesuai dengan SAP. Hal ini disebabkan karena laporan keuangan tahun sebelumnya telah dilakukan pemeriksaan oleh BPK dan hasil evaluasinya akan ditindaklanjuti untuk memperbaiki penyajian laporan keuangan pemerintah daerah pada tahun anggaran berikutnya. Dalam penelitian Syafitri (2012), salah satu variable yang digunakan adalah umur administratif Pemda yang hasilnya menemukan bahwa umur administratif Pemda berpengaruh positif dan signifikan terhadap pengungkapan LKPD.

Dari uraian di atas, maka hipotesis ketiga penelitian ini adalah: Umur administratif Pemda berpengaruh positif terhadap tingkat pengungkapan LKPD.

\section{Ukuran Legislatif (DPRD)}

Gilligan dan Matsusaka (2001) menggunakan legislature size sebagai variable independen dalam menguji pengaruhnya terhadap kebijakan fiskal di Pemda Amerika Serikat pada awal pertengahan abad ke- 20. Hasil penelitiannya menemukan bahwa legislature size secara signifikan dan positif berpengaruh terhadap kebijakan fiskal. Sistem pemerintahan Indonesia, yang berperan sebagai badan legislatif adalah Dewan Perwakilan Rakyat Daerah (DPRD). DPRD sebagai wakil masyarakat memiliki fungsi pengawasan, yaitu mengontrol jalannya pemerintahan agar selalu sesuai dengan aspirasi masyarakat dan mengawasi pelaksanaan dan pelaporan informasi keuangan Pemerintah Daerah agar tercipta suasana pemerintahan daerah yang transparan dan akuntabel. Syafitri (2012) menemukan bahwa jumlah anggota DPRD berpengaruh positif terhadap tingkat pengungkapan LKPD. Dengan demikian, semakin banyak jumlah anggota DRPD diharapkan semakin dapat meningkatkan pengawasan terhadap Pemda sehingga terdapat peningkatan pada pengungkapan LKPD. Dari uraian di atas, maka hipotesis keempat penelitian ini adalah: Jumlah anggota Dewan Perwakilan Rakyat Daerah (DPRD) berpengaruh positif terhadap tingkat pengungkapan LKPD.

\section{Jumlah Penduduk}

Jumlah penduduk merupakan proksi dari kompleksitas pemerintah. Semakin kompleks pemerintahan maka semakin besar pengungkapan yang harus mereka lakukan. Lestiani (2012) menemukan bahwa jumlah penduduk berkorelasi positif dan signifikan terhadap tingkat pengungkapan. Hilmi (2010) juga menemukan hubungan yang positif terhadap tingkat pengungkapan.

Berdasarkan uraian di atas, hipotesis kelima penelitian ini adalah sebagai berikut : Jumlah penduduk berpengaruh positif terhadap tingkat pengungkapan LKPD

\section{Jumlah Satuan Kerja Pemerintah Daerah (SKPD)}

Jumlah SKPD menggambarkan jumlah urusan yang menjadi prioritas pemerintah daerah dalam membangun daerah. Semakin banyak urusan yang menjadi prioritas pemerintah daerah maka semakin kompleks pemerintah tersebut. Jumlah SKPD merupakan proksi dalam menjelaskan kompleksitas pemerintah. Kompleksitas suatu pemerintahan dapat berarti semakin banyak jumlah SKPD semakin banyak 
Mira Feriyanti, Hermanto, Ni Ketut S Jurnal InFestasi Vol. 11, No.2, Desember 2015

informasi yang harus diungkapkan sebagai upaya mengurangi asimetri informasi dan menunjukkan kinerja steward yang semakin baik.

Berdasarkan uraian diatas, maka hipotesis keenam untuk penelitian ini adalah: H6 : Jumlah SKPD berpengaruh positif terhadap tingkat pengungkapan LKPD

\section{Jumlah Temuan Audit BPK}

Lestiani (2012) menemukan bahwa jumlah temuan audit BPK berkorelasi positif dan signifikan terhadap tingkat pengungkapan laporan keuangan pemerintah kabupaten/kota. Dengan adanya temuan ini, maka BPK akan meminta melakukan koreksi dan meningkatkan pengungkapannya. Sehingga, semakin besar jumlah temuan maka semakin besar jumlah tambahan pengungkapan yang akan diminta oleh BPK dalam laporan keuangan.

Berdasarkan uraian diatas, hipotesis ketujuh penelitian ini adalah : Jumlah temuan audit BPK berpengaruh positif terhadap tingkat pengungkapan LKPD.

\section{Tingkat penyimpangan audit BPK}

Hilmi (2010) menemukan bahwa tingkat penyimpangan berpengaruh positif dan signifikan terhadap tingkat pengungkapan laporan keuangan pemerintah prorvinsi. Penyimpangan yang meningkat yang dilakukan oleh aparat pemerintah akan mengurangi tingkat pengungkapan laporan keuangan. Hal ini dikarenakan aparat pemerintah berusaha menutupi penyimpangan yang mereka lakukan sehingga mengurangi pengungkapan yang dilakukan. Semakin besar tingkat penyimpangan maka semakin kecil pengungkapan yang dilakukan. Hipotesis kedelapan penelitian ini adalah : Tingkat penyimpangan audit BPK berpengaruh negative terhadap tingkat pengungkapan LKPD

\section{METODE PENELITIAN}

\section{Populasi Dan Sampel}

Populasi penelitian ini adalah Pemerintah Kabupaten/Kota di NTB yang terdiri dari 8 Pemerintah Kabupaten dan 2 Pemerintah Kota. Penelitian ini merupakan penelitian sampel jenuh karena mengambil seluruh Kabupaten/Kota di Provinsi NTB sebagai subjek penelitian. Data penelitian ini merupakan data sekunder berupa Laporan Keuangan Pemerintah Daerah yang telah diaudit oleh BPK Tahun Anggaran 2011 sampai dengan 2013, data dari Badan Pusat Statistik dan laporan ikhtisar hasil pemeriksaan BPK

\section{Variabel Penelitian}

Tingkat pengungkapan LKPD yang dimaksud ialah perbandingan antara pengungkapan yang telah disajikan dalam LKPD dengan pengungkapan yang seharusnya disajikan dalam Catatan atas Laporan Keuangan (CaLK) menurut Standar Akuntansi Pemerintah (SAP). Sistem scoring digunakan untuk mengukur tingkat pengungkapan. Sistem scoring merupakan system pemberian skor terhadap daftar checklist pengungkapan yang diwajibkan dalam SAP. Penggunaan sistem scoring ini serupa dengan penelitian yang dilakukan Lestiani (2012), Hilmi (2010) san Syafitri (2012).

Variabel kekayaan daerah dihitung dari Total PAD (Syafitri 2012). Tingkat ketergantungan dihitung dari Dana Alokasi Umum (DAU) dibandingkan dengan total pendapatan (Hilmi, 2010; Syafitri, 2012). Umur pemerintah daerah berdasarkan hari jadi pemerintah daerah (Syafitri, 2012). Ukuran Legislatif diukur dari jumlah anggota DPRD (Syafitri, 2012). Jumlah penduduk dapat dihitung berdasarkan jumlah penduduk yang mendiami suatu wilayah (Hilmi, 2010; Lestiani (2012). Jumlah SKPD diukur dengan menggunakan total seluruh SKPD yang terdapat dalam suatu daerah (Hilmi, 2010). Temuan audit merupakan jumlah kasus-kasus yang ditemukan BPK atas ketidakpatuhan daerah terhadap peraturan perundangundangan yang berlaku (Hilmi, 2010). Tingkat penyimpangan merupakan nominal penyimpangan yang dilakukan Pemda dibandingkan dengan total Belanja (Hilmi, 2010).

\section{Model Penelitian}

Model regresi dalam penelitian ini adalah sebagai berikut: 
Mira Feriyanti, Hermanto, Ni Ketut S Jurnal InFestasi Vol. 11, No.2, Desember 2015

\begin{tabular}{|c|c|}
\hline \multirow{3}{*}{\multicolumn{2}{|c|}{$\begin{array}{l}\text { DISCit }=\text { ait }+\beta 1 \text { WEALTHit }+ \\
\beta 2 \text { DEPENDit }+\beta 3 \text { AGEit }+\beta \text { 4LEGit }+ \\
\beta 5 \text { POPit }+\beta 6 \text { SKPDit }+\beta \text { FINDit } \\
\beta \text { SDEVit }+\varepsilon \text { it }\end{array}$}} \\
\hline & \\
\hline & \\
\hline Keterangan: & \\
\hline & $=$ Tk. pengungkapan LKPD \\
\hline NEALTH & $=$ Jumlh Kekayaan Daerah \\
\hline DEPEND & $=$ Tingkat ketergantungan \\
\hline GE & $=$ Umur Pemrintah Daerah \\
\hline LEG & = Ukuran Legislatif \\
\hline $\mathrm{OP}$ & $=$ Jumlah penduduk \\
\hline KPD & $=$ Jumlah SKPD \\
\hline ND & $=$ Jumlah temuan \\
\hline DEV & $=$ Tingkat Penyimpangan \\
\hline
\end{tabular}

\section{Teknik Analisis Penelitian}

Penelitian ini menggunakan analisis regresi berganda dengan menggunakan data panel. Metode analisis yang digunakan adalah regresi data panel dengan menggunakan software eviews 8 . Metode regresi yang digunakan adalah metode common effect, fixed effect dan random effect.

\section{PEMBaHASAN}

\section{Analisa Hasil Penelitian}

Berdasarkan hasil statistik menunjukkan bahwa nilai maksimum pengungkapan di Nusa Tenggara Barat terjadi di Kabupaten Lombok Tengah pada tahun 2013, yakni sebesar 0,89. Tingkat ini lebih besar daripada nilai tertinggi pengungkapan LKPD provinsi di Sumatera, yakni 0,79 pada periode 2010 (Syafitri, 2012). Sedangkan pengungkapan terendah adalah $0,45 \mathrm{di}$ Kabupaten Lombok Timur tahun 2011. Nilai rata-rata pengungkapan di NTB adalah 0,61 . Temuan ini lebih besar dari nilai rata-rata tingkat pengungkapan LKPD Kabupaten/Kota di Indonesia pada periode 2009, yakni 52\% (Syafitri, 2012) dan 46\% untuk pengungkapan LKPD Provinsi tahun 2006 sampai dengan 2009 (Hilmi, 2010)

Pengungkapan yang dilakukan Pemerintah Daerah menunjukkan adanya peningkatan dari tahun 2011 ke 2013. Pada tahun 2011 tingkat pengungkapan LKPD hanya 55\% meningkat $62 \%$ pada tahun 2012 dan $68 \%$ tahun 2013. Adanya peningkatan dalam pengungkapan laporan keuangan pemerintah daerah menunjukkan pemerintah daerah terus memperbaiki kualitas laporan keuangannya. Statistik deskriptif variabel independen dapat dilihat pada tabel 1 . Kekayaan daerah memiliki rata-rata Rp. 63.831.766.447, rata-rata tingkat ketergantungan pemerintah Kabupaten/Kota adalah 0.64. Umur pemerintah daerah berdasarkan hari jadinya, tertua dimiliki oleh Kab Bima yang berumur 373 tahun pada tahun 2013 dan termuda oleh Kabupaten Lombok Utara yang bermur 3 tahun. Jumlah anggota legislative rata-rata adalah 37 orang dengan rata-rata jumlah penduduknya 459.093 orang. Jumlah SKPD maximum adalah 55 buah, minimum 25 buah di Kabupaten Lombok Utara. Rata-rata jumlah temuan audit berjumlah 22 kasus setiap tahun. Sedangkan untuk rata-rata tingkat penyimpangan hasil audit di Kabupaten/Kota di Provinsi NTB adalah 0.001 .

\section{Hasil Uji Hipotesis}

Pemodelan dalam teknik regresi data panel menggunakan tiga pendekatan alternatif metode dalam pengolahannya. Pendekatan-pendekatan tersebut ialah (1) Metode Common Effect (OLS), (2) Metode Fixed Effect (FEM), dan (3) Metode Random Effect (REM). Berikut dipaparkan hasil analisis data masingmasing pendekatan dengan menggunakan program eviews 8 .

\section{Metode Common Effect (OLS)}

Tabel 1 merupakan output dari regresi data panel metode Common Effect (OLS) dengan eviews 8. 
Mira Feriyanti, Hermanto, Ni Ketut S Jurnal InFestasi Vol. 11, No.2, Desember 2015

Tabel 1. Regresi Data Panel dengan Metode Common Effect

\begin{tabular}{lrrrr}
\hline \multicolumn{1}{c}{ Variable } & Coefficient & Std. Error & t-Statistic & \multicolumn{1}{c}{ Prob. } \\
\hline PAD & $1.23 \mathrm{E}-12$ & $2.12 \mathrm{E}-13$ & 5.788643 & 0.0000 \\
DEPEND & 0.728290 & 0.139149 & 5.233869 & 0.0000 \\
AGE & -0.000324 & $8.51 \mathrm{E}-05$ & -3.802570 & 0.0010 \\
LEG & -0.011816 & 0.002982 & -3.962780 & 0.0007 \\
POP & $-1.26 \mathrm{E}-08$ & $1.12 \mathrm{E}-07$ & -0.111706 & 0.9121 \\
SKPD & 0.014744 & 0.001461 & 10.09312 & 0.0000 \\
FIND & -0.002462 & 0.001747 & -1.409611 & 0.1726 \\
DEV & -2.986913 & 0.911750 & -3.276023 & 0.0035 \\
\hline \multicolumn{5}{c}{ Weighted Statistics } \\
R-squared & 0.907481 & Mean dependent var & 1.469637 \\
Adjusted R-squared & 0.878044 & S.D. dependent var & 1.430443 \\
S.E. of regression & 0.084682 & Sum squared resid & 0.157762 \\
Durbin-Watson stat & 1.541159 & & \\
\hline \multicolumn{5}{c}{ Unweighted Statistics } \\
R-squared & 0.499822 & Mean dependent var & 0.613333 \\
Sum squared resid & 0.219711 & Durbin-Watson stat & 0.664105 \\
\hline
\end{tabular}

Sumber: Output Eviews

\section{Metode Fixed Effect (FEM)}

Data yang digunakan pada penelitian ini tidak memenuhi asumsi klasik khususnya multikolinieritas, hal ini mengakibatkan metode fixed effect pada eviews tidak dapat dijalankan. Multikolinieritas pada variabel-variabel independen ini dapat dilihat pada tabel 2 dan 3 berikut:

Tabel 2. Collinearity Statistics

\begin{tabular}{lrr}
\hline \multirow{2}{*}{ Model } & \multicolumn{2}{c}{ Collinearity Statistics } \\
\cline { 2 - 3 } (Constant) & \multicolumn{2}{c}{ Tolerance } \\
PAD &, 332 & 3,011 \\
DEPEND &, 465 & 2,153 \\
AGE &, 360 & 2,780 \\
LEG &, 061 & 16,430 \\
POP &, 109 & 9,158 \\
SKPD &, 351 & 2,848 \\
FIND &, 661 & 1,513 \\
DEV &, 770 & 1,300 \\
\hline
\end{tabular}

Tabel 3 menunjukkan bahwa nilai VIF untuk variabel jumlah anggota legislatif (LEG) sebesar 16,43 adalah lebih dari 10, maka menurut Gujarati (1993) terjadi multikolinieritas. Hal ini menunjukkan bahwa variabel jumlah anggota legislatif memiliki korelasi yang tinggi terhadap variabel independen lainnya. Berdasarkan tabel 4, dapat dilihat bahwa, variabel jumlah anggota legislatif berkorelasi tinggi (sebesar $0,895)$ dengan variabel jumlah penduduk (POP). Untuk itu, dapat disimpulkan bahwa multikolinieritas ini terjadi karena adanya korelasi yang tinggi antara variabel jumlah anggota legislatif dengan jumlah penduduk.

Tabel 3. Korelasi Antar Variabel

\begin{tabular}{llrrrrrrrrr}
\hline & \multicolumn{1}{c}{ DISC } & \multicolumn{1}{c}{ PAD } & DEPEND & \multicolumn{1}{c}{ AGE } & \multicolumn{1}{l}{ LEG } & \multicolumn{1}{l}{ POP } & SKPD & FIND & DEV \\
\hline & DISC & 1,000 &, 217 &, 274 &, 053 &, 235 &, 159 &, 476 &,- 050 &,- 120 \\
& PAD &, 217 & 1,000 &,- 399 &,- 190 &, 517 &, 509 &, 264 &,- 156 &,- 328 \\
& DEPEND &, 274 &,- 399 & 1,000 &, 370 &, 238 &, 162 &, 182 &, 268 &, 070 \\
Pearson & AGE &, 053 &,- 190 &, 370 & 1,000 &, 325 &, 032 &, 516 &, 130 &,- 038 \\
Correlation & LEG &, 235 &, 517 &, 238 &, 325 & 1,000 &, 895 &, 698 &,- 235 &,- 239 \\
& POP &, 159 &, 509 &, 162 &, 032 &, 895 & 1,000 &, 498 &,- 211 &,- 211 \\
& SKPD &, 476 &, 264 &, 182 &, 516 &, 698 &, 498 & 1,000 &,- 257 &, 029 \\
& FIND &,- 050 &,- 156 &, 268 &, 130 &,- 235 &,- 211 &,- 257 & 1,000 &,- 136 \\
& DEV &,- 120 &,- 328 &, 070 &,- 038 &,- 239 &,- 211 &, 029 &,- 136 & 1,000 \\
\hline
\end{tabular}

Untuk dapat menjalankan metode fixed effect, maka data variabel jumlah anggota legislatif (LEG) akan ditentukan turunan pertamanya atau $\operatorname{Lag}(1)$, sehingga hasil metode Fixed Effect adalah sebagai berikut: 
Mira Feriyanti, Hermanto, Ni Ketut S Jurnal InFestasi Vol. 11, No.2, Desember 2015

Tabel 4. Regresi Data Panel dengan Metode Fixed Effect

\begin{tabular}{|c|c|c|c|c|}
\hline Variable & Coefficient & Std. Error & t-Statistic & Prob. \\
\hline $\mathrm{C}$ & -4.035948 & 0.891698 & -4.526138 & 0.0007 \\
\hline PAD? & $-2.47 \mathrm{E}-13$ & $3.69 \mathrm{E}-13$ & -0.667668 & 0.5170 \\
\hline DEPEND? & -0.133967 & 0.249729 & -0.536448 & 0.6015 \\
\hline AGE? & 0.051984 & 0.011301 & 4.599788 & 0.0006 \\
\hline LEG? & -0.001066 & 0.000759 & -1.405599 & 0.1852 \\
\hline POP? & $2.96 \mathrm{E}-06$ & $2.62 \mathrm{E}-06$ & 1.129337 & 0.2808 \\
\hline SKPD? & -0.027754 & 0.013987 & -1.984285 & 0.0706 \\
\hline FIND? & 0.002564 & 0.001638 & 1.565427 & 0.1435 \\
\hline DEV? & -0.398592 & 0.734886 & -0.542387 & 0.5975 \\
\hline
\end{tabular}

Fixed Effects (Cross)

$\begin{array}{lr}\text { MTR-C } & 1.816576 \\ \text { LOBAR-C } & 1.223960 \\ \text { LOTENG-C } & 0.003481 \\ \text { LOTIM-C } & -0.079793 \\ \text { KLU-C } & 4.515739 \\ \text { KSB-C } & 4.886335 \\ \text { SBW-C } & 2.489326 \\ \text { DPU-C } & -5.204412 \\ \text { BIMA-C } & -14.38893 \\ \text { KOBI-C } & 4.737722 \\ & \text { Effects Specification }\end{array}$

Cross-section fixed (dummy variables)

Weighted Statistics

\begin{tabular}{llll} 
R-squared & 0.990167 & Mean dependent var & 0.975327 \\
Adjusted R-squared & 0.976237 & S.D. dependent var & 0.630482 \\
S.E. of regression & 0.033751 & Sum squared resid & 0.013669 \\
F-statistic & 71.08168 & Durbin-Watson stat & 2.762388 \\
Prob(F-statistic) & 0.000000 & & \\
& & & \\
& Unweighted Statistics & \\
R-squared & 0.949653 & Mean dependent var & 0.613333 \\
Sum squared resid & 0.022116 & Durbin-Watson stat & 2.003757 \\
\hline
\end{tabular}

Sumber: Output Eviews

Metode Random Effect (REM)

Tabel 5. Regresi Data Panel dengan Metode Random Effect

\begin{tabular}{|c|c|c|c|c|}
\hline Variable & Coefficient & Std. Error & t-Statistic & Prob. \\
\hline $\mathrm{C}$ & -0.154221 & 0.321559 & -0.479602 & 0.6365 \\
\hline PAD & $9.63 \mathrm{E}-13$ & $3.94 \mathrm{E}-13$ & 2.445100 & 0.0234 \\
\hline DEPEND & 0.917002 & 0.249720 & 3.672115 & 0.0014 \\
\hline AGE & -0.000296 & 0.000442 & -0.668923 & 0.5108 \\
\hline LEG & -0.010725 & 0.012941 & -0.828780 & 0.4165 \\
\hline POP & $8.57 \mathrm{E}-08$ & $3.14 \mathrm{E}-07$ & 0.273152 & 0.7874 \\
\hline SKPD & 0.012014 & 0.006103 & 1.968654 & 0.0623 \\
\hline FIND & 0.000870 & 0.002142 & 0.406058 & 0.6888 \\
\hline DEV & -1.703404 & 0.888818 & -1.916483 & 0.0690 \\
\hline
\end{tabular}

Random Effects (Cross)

MTR-C

0.019449

LOBAR-C -0.028426

LOTENG-C $\quad 0.148364$

LOTIM-C $\quad-0.132908$ 
Mira Feriyanti, Hermanto, Ni Ketut S Jurnal InFestasi Vol. 11, No.2, Desember 2015

\begin{tabular}{|c|c|c|c|c|}
\hline $\mathrm{KLU}-\mathrm{C}$ & -0.011867 & & & \\
\hline $\mathrm{KSB}-\mathrm{C}$ & 0.015462 & & & \\
\hline $\mathrm{SBW}-\mathrm{C}$ & 0.064516 & & & \\
\hline $\mathrm{DPU}-\mathrm{C}$ & -0.054069 & & & \\
\hline BIMA-C & 0.004569 & & & \\
\hline $\mathrm{KOBI}-\mathrm{C}$ & -0.025090 & & & \\
\hline \multicolumn{5}{|c|}{ Effects Specification } \\
\hline Cross-section random & & & $\begin{array}{c}\text { S.D. } \\
0.105815\end{array}$ & $\begin{array}{c}\text { Rho } \\
0.8809\end{array}$ \\
\hline Idiosyncratic random & & & 0.038907 & 0.1191 \\
\hline \multicolumn{5}{|c|}{ Weighted Statistics } \\
\hline R-squared & 0.465728 & Mean dependent var & & 0.127363 \\
\hline Adjusted R-squared & 0.262196 & S.D. dependent var & & 0.063636 \\
\hline S.E. of regression & 0.054660 & Sum squared resid & & 0.062743 \\
\hline F-statistic & 2.288227 & Durbin-Watson stat & & 1.815513 \\
\hline Prob(F-statistic) & 0.061499 & & & \\
\hline \multicolumn{5}{|c|}{ Unweighted Statistics } \\
\hline R-squared & 0.507587 & Mean dependent var & & 0.613333 \\
\hline Sum squared resid & 0.216301 & Durbin-Watson stat & & 0.526632 \\
\hline
\end{tabular}

Sumber: Output Eviews

Tabel 6. Perbandingan Nilai koefisien dan Probabilitas Metode Common Effect, Metode Fixed Effect dan Metode Random Effect

\begin{tabular}{lrlrlrl}
\hline \multirow{2}{*}{ Variabel } & \multicolumn{2}{c}{ Common Effect } & \multicolumn{2}{c}{ Fixed Effect } & \multicolumn{2}{c}{ Random Effect } \\
\cline { 2 - 7 } & \multicolumn{1}{c}{ Koefisien } & \multicolumn{1}{c}{ Prob } & \multicolumn{1}{c}{ Koefisien } & \multicolumn{1}{c}{ Prob } & \multicolumn{1}{l}{ Koefisien } & \multicolumn{1}{l}{ Prob } \\
\hline PAD & $1.23 \mathrm{E}-12$ & 0.0000 & $-2.47 \mathrm{E}-13$ & 0.5170 & $9.62 \mathrm{E}-13$ & 0.0234 \\
DEPEND & 0.728290 & 0.0000 & -0133967 & 0.6015 & 0.917002 & 0.0014 \\
AGE & -0.000324 & 0.0010 & 0.051984 & 0.0006 & -0.000296 & 0.5108 \\
LEG & -0.011816 & 0.0007 & -0.001066 & 0.1852 & -0.010725 & 0.4165 \\
POP & $-1.26 \mathrm{E}-08$ & 0.9121 & $2.96 \mathrm{E}-06$ & 0.2808 & $8.57 \mathrm{E}-08$ & 0.7874 \\
SKPD & 0.014744 & 0.0000 & -0.027754 & 0.0706 & 0.012014 & 0.0623 \\
FIND & -0.002462 & 0.1726 & 0.002564 & 0.1435 & 0.000870 & 0.6888 \\
DEV & -2.986913 & 0.0035 & -0.398592 & 0.5975 & -1.703404 & 0.0690 \\
\hline
\end{tabular}

Tabel 7. Perbandingan hasil uji Metode Common Effect, Fixed Effect dan Random Effect

\begin{tabular}{cccc}
\hline Hasil & Common Effect & Fixed Effect & Random Effect \\
\hline $\mathrm{R}^{2}$ & 0.907481 & 0.990167 & 0.465728 \\
Variabel Signifikan & $\begin{array}{c}\text { PAD, Depend, Age, } \\
\text { Leg, SKPD, Dev }\end{array}$ & Age & $\begin{array}{c}\text { Depend, SKPD, } \\
\text { Dev }\end{array}$ \\
\hline
\end{tabular}

\section{Pemilihan Model Terbaik}

Menurut Ghozali (2013), ketepatan fungsi regresi sampel dalam menaksir nilai aktual dapat diukur dari goodness of fit. Secara statistic, salah satunya dapat diukur dari nilai koefisien determinasi $\left(\mathrm{R}^{2}\right)$. Koefisien determinasi mengukur seberapa jauh kemampuan model dalam menerangkan variasi variabel dependen. Kadangkala peneliti ingin memaksimumkan nilai $\mathrm{R}^{2}$ sehingga mencari model yang menghasilkan nilai
$\mathrm{R}^{2}$ tinggi. Hal ini jika dilakukan dapat berbahaya karena tujuan analisis tujuan analisis regresi bukan semata ingin mendapatkan nilai $\mathrm{R}^{2}$ tinggi, tetapi mencari nilai estimasi koefisien regresi dan menarik inferensi statistik. Dalam kenyataan empiris biasa ditemukan regresi dengan nilai $\mathrm{R}^{2}$ tinggi, tetapi nilai koefisien regresi tidak ada yang signifikan atau memiliki tanda koefisien yang berlawanan dari yang diharapkan secara teori. 
Mira Feriyanti, Hermanto, Ni Ketut S Jurnal InFestasi Vol. 11, No.2, Desember 2015

Pada penelitian ini, koefisien regresi $\left(\mathrm{R}^{2}\right)$ pada metode fixed effect sebesar 0.99, metode common effect sebesar 0.90 dan metode random effect sebesar 0.46. Nilai $\mathrm{R}^{2}$ metode fixed effect lebih tinggi daripada metode common effect, akan tetapi karena tujuan analisis regresi bukan semata ingin mendapatkan nilai $\mathrm{R}^{2}$ tinggi, maka perlu dianalisis lebih jauh dengan melihat nilai koefisien regresi masing-masing hasil pengujian. Pada metode fixed effect dihasilkan nilai koefisien regresi $\left(\mathrm{R}^{2}\right)$ yang paling tinggi tetapi kecil dari jumlah nilai koefisien regresi yang signifikan. Dengan melihat pada logika atau penjelasan teoritis pengaruh variabel explanatory terhadap variabel dependen maka model terbaik yang dipilih adalah metode common effect. Jika dalam proses mendapatkan nilai $\mathrm{R}^{2}$ tinggi adalah baik, tetapi jika nilai $\mathrm{R}^{2}$ rendah tidak berarti model regresi jelek (Ghozali, 2013).

Insukindro dalam Ghozali (2013) mengatakan bahwa koefisien determinasi hanyalah salah satu dan bukan satusatunya kriteria memilih model yang baik. Alasannya bila suatu estimasi regresi linear menghasilkan koefisien determinasi yang tinggi, tetapi tidak konsisten dengan teori ekonomika yang dipilih oleh peneliti, atau tidak lolos dari uji asumsi klasik, maka model tersebut bukanlah model penaksir yang baik dan seharusnya tidak dipilih menjadi model empiris.

Firmansyah (2008) juga manyatakan bahwa untuk kebutuhan yang lebih luas, interpretasi ketiga model tersebut adalah tetap layak digunakan. Perbandingan ketiga metode analisis pada tabel 6 dan 7 memberikan kesimpulan akhir berdasarkan $\mathrm{R}^{2}$, pengaruh variabel explanatory terhadap variabel dependen dan terdapat uji multikolinearitas yang tidak lolos pada metode fixed effect dapat disimpulkan bahwa model terbaik pada penelitian ini adalah metode common effect dengan persamaan sebagai berikut :

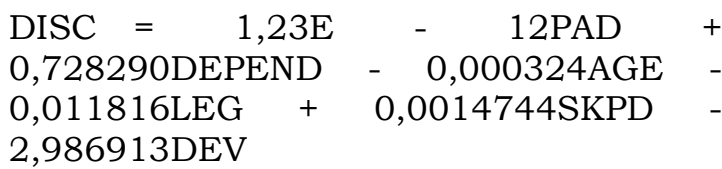

\section{Pengaruh Kekayaan Pemerintah Daerah terhadap Pengungkapan Laporan Keuangan.}

Berdasarkan pada hasil pengujian regresi, kekayaan pemerintah daerah memiliki koefisien regresi positif sebesar 1.23E-12 dan nilai signifikansi (prob) sebesar 0.0000 lebih kecil dari $a=5 \%$ yang berarti hipotesis satu dapat diterima. Artinya bahwa variabel kekayaan Pemerintah daerah memiliki hubungan positif dan signifikan terhadap tingkat pengungkapan LKPD pada tingkat keyakinan 95\%. Semakin tinggi tingkat kekayaan yang dimiliki Pemerintah Daerah maka semakin memberikan tekanan kepada pemerintah daerah untuk melakukan pengungkapan secara lengkap.

Variabel Kekayaan daerah diproksikan dengan Pendapatan Asli Daerah (PAD). Pendapatan Asli Daerah merupakan penerimaan dalam wilayahnya sendiri yang bersumber dari masyarakat yang terdiri dari pajak daerah, retribusi daerah dan penerimaan lainnya. Jika PAD yang dimiliki daerah jumlahnya besar maka dapat dikatakan bahwa partisipasi masyarakat dalam membayar pajak dan retribusi daerah besar. Hal ini mendorong pemerintah daerah melakukan pengungkapan dalam laporan keuangannya agar transparan dan akuntabel. Hasil penelitian ini sejalan dengan penelitian yang dilakukan oleh Hilmi (2010), Syafitri (2012), Lestiani (2012) yang mengungkapkan bahwa semakin tinggi tingkat kekayaan daerah, semakin tinggi pengungkapan yang dilakukan.

\section{Pengaruh Tingkat Ketergantungan Pemerintah Daerah terhadap Pengungkapan Laporan Keuangan.}

Berdasarkan pada hasil pengujian regresi, tingkat ketergantungan Pemerintah Daerah memiliki koefisien regresi positif sebesar 0.728290 dan nilai signifikansi (prob) sebesar 0.0000 lebih kecil dari $a=5 \%$ yang berarti hipotesis kedua dapat diterima. Artinya bahwa variable tingkat ketergantungan Pemerintah Daerah memiliki hubungan positif terhadap tingkat pengungkapan LKPD pada tingkat keyakinan 95\%. 
Mira Feriyanti, Hermanto, Ni Ketut S Jurnal InFestasi Vol. 11, No.2, Desember 2015

Dana transfer merupakan jenis pendanaan daerah yang berasal dari pemerintah pusat atau provinsi. Oleh karena itu, pemerintah pusat ataupun provinsi akan meminta pengungkapan yang lebih sebagai upaya untuk memonitor kinerja pemerintah daerah atas penggunaan dana tersebut. Artinya semakin besar tingkat ketergantungan maka semakin besar tingkat pengungkapan yang dilakukan pemerintah daerah. Pertanggungjawaban atas penggunaan dana tersebut merupakan upaya pemerintah daerah dalam menjalani tanggungjawabnya. Tanggung jawab melalui bentuk transparansi dan akuntabilitas pengelolaan keuangan daerah sekaligus untuk mewujudkan kepercayaan publik baik kepada masyarakat maupun pemerintah pusat atau provinsi bahwa dana yang diberikan tidak disalahgunakan (korupsi).

Adanya ketergantungan yang besar memungkinkan pemerintah pusat untuk melakukan pembatasan operasi pemerintahan daerah Kabupaten/Kota dan meminta pengungkapan lebih untuk memonitor kinerja pemerintah daerah. Insentif pelaporan keuangan yang mulai diberikan sejak tahun 2010 untuk pencapaian opini juga memberikan stimulus pemerintah daerah untuk meningkatan kualitas pengungkapan. Penelitian ini sejalan dengan penelitian Khasanah (2014) dan penelitian Austin dan Robbins (1986) yang menemukan bahwa tingkat ketergantungan pemerintah kota berhubungan positif dan signifikan terhadap tingkat pengungkapan laporan keuangan pemerintah kota

\section{Pengaruh Umur Administratif Pemda terhadap Tingkat Pengungkapan LKPD}

Berdasarkan hasil pengujian regresi, umur administrative Pemerintah Daerah memiliki koefisien regresi negatif sebesar -0.000324 dan nilai signifikansi (prob) sebesar 0.0010 lebih besar dari $a=5 \%$ yang berarti hipotesis 3 tidak terbukti. Artinya, bahwa variabel umur administratif Pemerintah Daerah memiliki hubungan negatif tidak signifikan terhadap tingkat pengungkapan LKPD. Variabel umur pemerintahan memiliki koefisien negatif, artinya semakin lama umur administrasi pemerintahan, justru menyebabkan pengungkapan menjadi semakin rendah.

Penelitian Khasanah (2014)

menunjukan hasil yang sama di Pemda Kabupaten/Kota di Propinsi Jawa Tengah. Penelitian Wardani (2012) menunjukkan hubungan negatif yang dihubungkan dengan luas pengungkapan sukarela. Hasil serupa turut dikemukakan oleh Aprilia (2007) yang menemukan hubungan negatif antara umur dengan kualitas pengungkapan sukarela laporan tahunan.

Adanya hubungan negatif antara umur administratif Pemerintah Daerah dan tingkat pengungkapan LKPD kemungkinan disebabkan karena di Propinsi Nusa Tenggara Barat, terdapat dua Pemda dengan usia yang lebih tua dari umur Republik Indonesia yaitu Kabupaten Bima, yang berusia 373 tahun dan Kabupaten Dompu yang berusia 198 tahun pada tahun 2013. Sedangkan pemda termuda adalah Pemda Kabupaten Lombok Utara, yakni baru berusia 5 tahun pada tahun 2013 . Berarti Pemda Kabupaten Bima telah berdiri sebelum Indonesia merdeka. Undang-undang pembentukan Kabupaten Bima dan Kabupaten Dompu mengisyaratkan bahwa kedua daerah tersebut usianya disematkan pada umur kerajaan atau kesultanan di kedua daerah tersebut. Pelaporan keuangan merupakan ilmu yang berkembang dinamis sehingga tidak menjadi jaminan bahwa Pemda dengan umur yang lebih tua akan dapat menghasilkan kualitas pelaporan keuangan yang lebih baik jika tidak ditunjang dengan kemauan dan kemampuan pelakunya.

\section{Pengaruh Ukuran legislatif (DPRD) terhadap tingkat pengungkapan LKPD}

Dalam penelitian ini, ukuran legislatif memiliki pengaruh signifikan dengan arah negatif terhadap tingkat pengungkapan LKPD Kabupaten/Kota di Provinsi Nusa Tenggara Barat periode 2011-2013. Ukuran legislastif memiliki koefisien regresi negative sebesar 0.011816 dan nilai signifikansi (prob) sebesar 0.0007 lebih kecil dari nilai $\mathrm{a}=$ $5 \%$ yang berarti bahwa hipotesis keempat 
Mira Feriyanti, Hermanto, Ni Ketut S Jurnal InFestasi Vol. 11, No.2, Desember 2015

juga tidak terbukti. Artinya, bahwa variabel ukuran legislatif memiliki hubungan negatif signifikan terhadap tingkat pengungkapan LKPD pada tingkat keyakinan 95\%. Dengan kata lain semakin banyak anggota DPRD semakin rendah tingkat pengungkapan LKPD.

Hasil penelitian ini sejalan dengan penelitian Sumarjo (2010). Walaupun menurut teori dinyatakan bahwa semakin besar ukuran legislatif semakin tinggi tingkat pengawasan yang kemudian berdampak semakin baik kinerja dan pengungkapan yang dilakukan pemerintah daerah. Namun hal tersebut tidak sepenuhnya bisa dilaksanakan akibat kuantitas yang lebih diutamakan daripada kualitas. Jumlah anggota DPRD yang banyak tidak diikuti adanya fungsi dan peran yang semakin baik, sehingga fungsi pengawasan yang seharusnya dimiliki anggota DPRD tidak bisa dimaksimalkan. Banyaknya isu tentang korupsi yang dilakukan anggota DPRD juga turut menyumbang alasan atas penurunan kinerja pemerintah yang kemudian berdampak pula pada penurunan kinerja atas tingkat pengungkapan laporan keuangan (Sumarjo, 2010).

\section{Pengaruh Jumlah Penduduk Terhadap Tingkat Pengungkapan Laporan Keuangan}

Bedasarkan hasil pengujian regresi, jumlah penduduk memiliki koefisien regresi -1.26E-08 dan prob sebesar 0.9. Nilai Prob yang lebih besar dari $a=5 \%$ berarti bahwa hipotesis kelima ditolak, jumlah penduduk tidak berpengaruh terhadap tingkat pengungkapan Laporan Keuangan Pemerintah Kabupaten/Kota di Provinsi NTB.

Hasil penelitian ini berbeda dengan hipotesis bahwa jumlah penduduk berhubungan positif dan signifikan dengan tingkat pengungkapan. Hasil penelitian ini menolak aumsi bahwa semakin besar jumlah penduduk maka semakin besar pengungkapan yang harus dilakukan pemerintah daerah dalam laporan keuangan. Meskipun jumlah penduduk banyak namun belum tentu memahami dan mengerti dengan Laporan Keuangan Pemerintah Daerah sebagai bentuk pertanggungjawaban agen terhadap prinsipal.

Nusa Tenggara Barat sebagai daerah yang tergolong miskin dengan tingkat Indeks Pembanguna Manusia (IPM) yang berada dirangking 33 dari 34 provinsi di Indonesia. Bedasarkan data BPS, persentase penduduk usia 15 tahun keatas yang belum pernah sekolah relatif tinggi, sehingga menyumbang angka masyarakat buta huruf. Demikian juga dengan tingginya angka dropout atau putus sekolah penduduk usia 15 tahun keatas terutama pada jenjang sekolah dasar.

\section{Jumlah SKPD Berpengaruh terhadap Tingkat Pengungkapan Laporan Keuangan}

Jumlah SKPD berpengaruh positif terhadap tingkat pengungkapan laporan keuangan pemerintah daerah. Koefisien sebesar 0.014744 dan probabilitas 0.0000 . Adanya hubungan positif berarti semakin banyak jumlah SKPD semakin tinggi tingkat pengungkapan. Hasil penelitian ini sesuai dengan hipotesis keenam bahwa jumlah SKPD berhubungan positif dan signifikan dengan tingkat pengungkapan. Hasil ini sejalan dengan penelitian yang dilakukan oleh Patrick (2007) yang menunjukkan bahwa Pemerintah daerah dengan tingkat diferensiasi fungsional yang lebih tinggi cenderung untuk melakukan pengungkapan yang lebih tinggi. Hasil penelitian ini sejalan dengan penelitian Hilmi (2010) yang menemukan bahwa jumlah unit di bawah Propinsi tidak berpengaruh secara signifikan terhadap tingkat pengungkapan laporan keuangan propinsi

\section{Jumlah Temuan Audit BPK Berpengaruh terhadap Tingkat Pengungkapan LKPD}

Variabel jumlah temuan audit BPK (FIND) tidak berpengaruh terhadap tingkat pengungkapan LKPD Kabupaten/Kota di Provinsi NTB periode 2011-2013. Berdasar uji hipotes, nilai koefisien tingkat penyimpangan adalah 0.002462 dan prob 0.1726 sehingga hipotesis ketujuh ditolak. Hasil negatif menyatakan bahwa semakin sedikit temuan audit semakin baik tingkat 
Mira Feriyanti, Hermanto, Ni Ketut S Jurnal InFestasi Vol. 11, No.2, Desember 2015

pengungkapan. Artinya dengan sedikitnya pelanggaran yang dilakukan pemerintah daerah (sedikitnya jumlah temuan audit) maka tingkat pengungkapan yang dilakukan lebih tinggi daripada daerah dengan temuan audit yang lebih besar.

Hasil penelitian ini sejalan dengan penelitian Hilmi (2010) yang menemukan temuan audit tidak berpengaruh secara signifikan terhadap tingkat pengungkapan laporan keuangan propinsi dan Sudarsana (2013) yang menghubungkan temuan audit dengan kinerja pemerintah. Tidak signifikan terjadi karena belum berjalannya proses pengurangan asimetri informasi yang seharusnya. Jumlah temuan audit BPK tidak serta merta mendorong pemerintah daerah dalam meningkatkan pengungkapannya. Pelaksanaan revisi maupun kritik dari BPK hanya sebatas pemenuhan kewajiban tanpa ada hubungan langsung dengan tingkat pengungkapan.

\section{Tingkat Penyimpangan audit BPK berpengaruh terhadap tingkat pengungkapan LKPD}

Tingkat penyimpangan berdasarkan audit BPK berpengaruh negatif terhadap tingkat pengungkapan. Nilai koefisien sebesar -2.986913 dan prob 0.0035 . Hipotesis kedelapan ini terbukti bahwa tingkat penyimpangan audit BPK berpengaruh negatif terhadap tingkat pengungkapan laporan keuangan. Semakin tinggi tingkat penyimpangan audit BPK ternyata tidak mendorong pemerintah daerah untuk melakukan pengungkapan lebih besar bahkan ada kecenderungan pemerintah daerah untuk menyembunyikan tingkat penyimpangan tersebut dari pengguna laporan keuangan. Hasil penelitian ini sejalan dengan penelitian Lestiani (2012) yang menemukan bahwa semakin besar tingkat penyimpangan semakin kecil pengungkapan yang dilakukan

\section{PENUTUP}

\section{Simpulan}

Penelitian ini bertujuan untuk menguji dan menganalisis pengaruh karakteristik Pemerintah Daerah, Kompleksitas
Pemerintahan dan temuan audit Kabupaten/Kota di Provinsi Nusa Tenggara Barat tahun 2011 -2013. Berdasarkan hasil pengujian ditemukan bahwa rata-rata tingkat pengungkapan Laporan Keuangan Pemerintah Daerah (LKPD) Kabupaten/Kota di Provinsi Nusa Tenggara Barat selama periode 20112013 adalah sebesar 61\%. Tingkat pengungkapan yang dilakukan oleh pemerintah daerah menunjukkan adanya peningkatan dari tahun 2011-2013 yang menunjukkan bahwa pemerintah daerah berusaha untuk terus memperbaiki kualitas laporan keuangannya.

Hasil penelitian ini menemukan bahwa dari 8 (delapan) variabel yang diuji 6 (enam) variabel independen memberikan pengaruh terhadap tingkat pengungkapan wajib Laporan keuangan pemerintah Daerah Kabupaten/Kota di Provinsi Nusa Tenggara Barat pada tahun 2011-2013. Variabel yang berpengaruh positif yaitu tingkat kekayaan daerah, tingkat ketergantungan dan jumlah SKPD. Variabel umur pemerintah daerah, jumlah anggota legislatif dan temuan audit memiliki pengaruh dengan arah negative. Variabel jumlah penduduk dan jumlah temuan audit tidak terbukti mempunyai pengaruh terhadap tingkat pengungkapan Laporan Keuangan Pemerintah Daerah Kabupaten/kota di Provinsi NTB tahun 2011-2013.

\section{Keterbatasan dan Saran}

Penelitian ini memiliki beberapa keterbatasan yang memerlukan perbaikan dalam penelitian-penelitian selanjutnya. Keterbatasan dalam penelitian ini adalah : (1) Karakteristik Pemerintah Daerah, kompleksitas pemerintahan dan temuan audit hanya menjelaskan sebagian dari faktor-faktor yang mempengaruhi tingkat pengungkapan laporan keuangan pemerintah daerah. Masih ada faktorfaktor lain yang dapat menjelaskan tingkat pengungkapan laporan keuangan pemerintah daerah yang tidak dimasukkan kedalam penelitian ini karena keterbatasan waktu dan data penelitian, dan (2) Penelitian ini menggunakan indeks pengungkapan 
Mira Feriyanti, Hermanto, Ni Ketut S Jurnal InFestasi Vol. 11, No.2, Desember 2015

yang dianggap memiliki bobot yang sama penting.

Keterbatasan-keterbatasan pada penelitian memerlukan perbaikan dalam penelitian-penelitian selanjutnya. Disarankan pada peneliti selanjutnya untuk meneliti tingkat pengungkapan wajib LKPD berdasarkan standar akuntansi pemerintahan yang diatur dalam PP 71 Tahun 2010 basis akrual yang mulai wajib diterapkan oleh seluruh pemerintah daerah tahun 2015. Peneliti selanjutnya juga dapat memberikan pembobotan terhadap item-item yang diungkapkan dalam laporan keuangan dan menambahkan variabel lain yang mempengaruhi tingkat pengungkapan LKPD seperti latar belakang pendidikan penyusun laporan keuangan.

\section{DAFTAR PUSTAKA}

Evans, J., Patton, J., 1987. Signaling and monitoring in public sector accounting. Journal ofAccounting Research 25 (Supplement), 130158.

Firmansyah, M. 2013. Ekonometrika Aplikasi Regresi, Poling Analysis dn Uji Kausalitas. Arga Puji Press. Mataram Lombok

Ghozali, Imam, 2013. Aplikai Multivariate dan Ekonometrika. Teori, Konsep dan Aplikasi dengan Eviews 8. Badan Penerbit Universitas Diponegoro, Semarang

Gujarati, Damodar. 2005. Ekonometrika Dasar. Jakarta: Erlangga

Halim, A. dan Abdullah, S. 2006. Hubungan dan Masalah Keagenan di Pemerintahan Daerah. Jurnal Akuntansi Pemerintahan Vol. 2 No. 1 pp 53-54

Hilmi, Amiruddin Zul. 2010. "Analisis Faktor-Faktor yang Mempengaruhi Tingkat Pengungkapan Laporan Keuangan Pemerintah Provinsi". Jurnal ASPAK No. 17 Universitas Indonesia

Ingram, R. W. (1984). Economic Incentives and the Choice of State Government

Accounting Practices. Journal of Accounting Research, Vol. 22 No.1 pp 125-144
James, A. Hall, 2007. Sistem Informasi Akuntansi. Edisi Ketiga, Terjemahan Amir Abadi Yusuf, Salemba Empat, Jakarta.

Jensen, M and Meckling. 1976. Theory of the firm : Managerial Behavior, agency cost and ownership structure, Journal of Financial Economics 3 (4) : 305 -360.

Kawedar, warsito dkk, 2008. Akuntansi Sektor Publik, Semarang UNDIP.

Khasanah, Nur lailatul 2014. "Pengaruh Karakteristik, Kompleksitas dan Temuan Audit terhadap Tingkat Pengungkapan Laporan Keuangan Pemerintah Daerah. Diponegoro Journal of Accounting Volume 3, Nomor 3, Tahun 2014, Halaman 111

Lasward, F., Fisher, R., dan Oyelere, P. 2005. Determinant of Voluntary Internet Financial Reporting by Local Government Authorities. Journal of Accounting and Public Policy. 24 (2), 101.121

Lesmana, Sigit I. 2010. "Pengaruh Karakteristik Pemerintah Daerah Terhadap Tingkat Pengungkapan Wajib di Indonesia”. Thesis, Fakultas Ekonomi Universitas Sebelas Maret, Surakarta.

Lestiani Annisa and Martani, Dwi 2012. Disclosure in Local Government Financial Statements : the Case of Indonesia. Global Review of Accounting and Finance Vol. 3. No. 1. March 2012. $67-84$

Mardiasmo 2004. Akuntansi Sektor Publik (Edisi Kedua). Andi : Yogyakarta

Patrick, Patricia A. 2007. The determinants of organizational innovativeness: The adoption of GASB 34 in Pennsylvania local government. Ph.D. dissertation, The Pennsylvania State University, United States - Pennsylvania. (Retrieved August 8, 2011, from Accounting \& Tax Periodicals, Publication No. AAT 3266180

Peraturan Pemerintah RI No. 24 Tahun 2005 Tentang Standar Akuntansi Pemerintahan.

Peraturan Pemerintah No. 71 Tahun 2010 Tentang Standar Akuntansi Pemerintahan. 
Mira Feriyanti, Hermanto, Ni Ketut S Jurnal InFestasi Vol. 11, No.2, Desember 2015

Peraturan Menteri Dalam Negeri RI No. 13 Tahun 2006 Tentang Pengelolaan Keuangan Daerah.

Robbin, W. A., \& Austin, K. R. 1986. Disclosure Quality in Governmental Financial Reports: An Assessment of The Appropriatness of a Compound Measure. Journal of Accounting Research.

Rosadi, Dedi. 2011. Ekonometrika dan Analisis Runtun Waktu Terapan dengan E Views. Andi : Yogyakarta

Santosa, P. B., dan Rahayu, R. P. 2005. Analisis Pendapatan Asli Daerah Dan Faktor-Faktor yang Mempengaruhinya Dalam Upaya Pelaksanaan Otonomi Daerah di Kabupaten Kediri. Dinamika Pembangunan. Vol. 2 No. 1.

Sudarsana, Hafidh Susila. 2013. Pengaruh Karakteristik Pemerintah Daerah dan Temuan Audit BPK terhadap Kinerja Pemerintah Daerah (Studi Pada Pemerintah Kabupaten/Kota di Indonesia)

Suhardjanto, Djoko, dan Rena Rukmita Yulianingtyas. 2011. Pengaruh Karakteristik Pemerintah Daerah terhadap Kepatuhan
Pengungkapan Wajib dalam Laporan Keuangan Pemerintah Daerah (Studi Empiris pada Kabupaten/Kota di Indonesia. Jurnal Akuntansi dan Auditing Vol.8 No. 1. November 2011.

Syafitri, Febriani. 2012. Analisis pengaruh karakteristi Pemda terhadap pengungkapan Laporan Keuangan, Jurnal Akuntansi dan Keuangan Indonesia Vol. 2 Edisi 9

Undang-Undang RI No. 17 Tahun 2003 tentang Keuangan Negara.

Undang-Undang RI No. 1 Tahun 2004 tentang Perbendaharaan Negara.

Undang-Undang RI No. 15 Tahun 2004 tentang Pemeriksaan Keuangan Negara.

Undang-Undang RI No. 32 Tahun 2004 Tentang Pemerintah Daerah.

Undang-Undang RI No. 33 Tahun 2004 tentang Peimbangan Keuangan antara Pemerintah Pusat dan Pemda

Zimmerman, J. L. 1977. The Municipal Accounting Maze: An Analysis of Political Incentives. Journal of Accounting Research. 